OPEN ACCESS

Edited by:

Amy E. Duchelle,

Center for International Forestry

Research (CIFOR), Indonesia

Reviewed by:

Rajan Parajuli,

North Carolina State University,

United States

Stella Schons,

Virginia Tech, United States

*Correspondence:

Karuna Paude

karunapaude/@uga.edu

Specialty section:

This article was submitted to

People and Forests,

a section of the journal

Frontiers in Forests and Global

Change

Received: 25 September 2020

Accepted: 29 March 2021

Published: 20 May 2021

Citation:

Paudel K and Dwivedi P (2021)

Economics of Southern Pines With and Without Payments

for Environmental Amenities in the US

South.

Front. For. Glob. Change 4:610106.

doi: 10.3389/ffgc.2021.610106

\section{Economics of Southern Pines With and Without Payments for Environmental Amenities in the US South}

\author{
Karuna Paude/* and Puneet Dwivedi \\ Warnell School of Forestry and Natural Resources, University of Georgia, Athens, GA, United States
}

During the early 1900s, nearly 37 million hectares of land in the Southern United States were under longleaf pine (Pinus palustris) relative to the current area of 1.6 million hectares. This study compares the economics of southern pines (longleaf, loblolly (Pinus taeda), and slash (Pinus elliottii)) to facilitate the decision making of family forest landowners and design suitable financial incentives for increasing the area under longleaf pine in the region. We simulated six growth and yield scenarios for selected southern pines over three site indices in the Lower Coastal Plain of South Georgia. We estimated land expectation values (LEVs) of each scenario for the three cases, i.e., payment for forest products, payment for forest products and net carbon storage, and payment for forest products, net carbon storage, and net water yield. Our findings show that pine straw income significantly increases the LEV of longleaf pine. The financial risk of growing longleaf pine is lower than that of other southern pines. Existing financial support through various governmental incentives or additional monetary support for ecosystem services provided by longleaf pine ecosystems is needed to increase the area under longleaf pine in the Southern United States, in general, and in South Georgia, in particular. However, a need exists to reevaluate the conservation values provided by longleaf plantations considering expected shorter rotation ages due to the income provided by pine straw markets in Southern United States.

Keywords: ecosystem services, economics, Southern United States, yellow pines, forest economics, carbon, water yield

\section{MANAGEMENT AND POLICY IMPLICATIONS}

Logging, agricultural expansion, conversion to commercial pine plantations, and fire suppression have led to the depletion of longleaf pine in Southern United States. Planting longleaf pine has become attractive over the past two decades due to the risks related to changing climate, the growth of markets for forest-based ecosystem services, strong governmental support, and the annual income potential for pine straw well before the first thinning age. Despite all the efforts to restore longleaf pine by various organizations, there has been no net change in the area of longleaf pine in the past 5 years. This study directly contributes to the current longleaf pine restoration initiatives for increasing the efficacy of existing financial resources in restoring longleaf pine. This study 
guides current longleaf pine initiatives that are increasingly relying on markets for ecosystem services for designing monetary incentives to increase the participation of southern private forest landowners in longleaf pine restoration.

\section{INTRODUCTION}

Out of 310 million hectares of forestlands in the United States, 26 million hectares are under plantations, out of which 19 million hectares are in the Southern United States alone (Miles, 2019). Currently, loblolly and slash pine plantations cover nearly 16 million hectares $(84 \%)$ of the total planted forests across southern states (Miles, 2019). However, before European settlement, longleaf pine was one of the most extensive forest cover types in the United States, covering about 23 million hectares alone and covering another 14 million hectares as a part of mixed-pine oak forest type (Oswalt et al., 2012; Miles, 2019). Logging, conversion to commercial pine plantations, and degradation through policies focusing on fire suppression led to the depletion of the area under longleaf pine. Currently, longleaf pine occupies only 1.6 million hectares in the Southern United States, i.e., only about $5 \%$ of the original distribution (Guldin et al., 2016).

Over the past two decades, interest in planting longleaf pine relative to other southern pines has increased among family forest landowners for two reasons. First, climate change will most likely increase drought events coupled with higher rainfall variability in the region (Wear and Greis, 2012). Climate change will also lead to higher incidences of forest fires, hurricanes, disease events, and pest attacks (Johnsen et al., 2009; Samuelson et al., 2014). Several studies have noted that longleaf pine is more resilient to the expected climate changes as it can grow in dry and wet conditions, has a higher fire-tolerant capacity, and is resistant to beetle infestation (Van Lear et al., 2005; Oswalt et al., 2012; Samuelson et al., 2014). This could decrease the financial risk posed by changing climate for southern family forest landowners.

Additionally, markets for ecosystem services are developing in the region where monetary incentives are available for forestbased ecosystem services. For example, conservation crediting strategy offers credits to offset the loss of endangered species, mitigation banking offsets the loss in wetlands and streams, and voluntary carbon markets pay for the net carbon stored in the forests (Bauer et al., 2004; Lave, 2018). A well-managed longleaf pine stand with an understory and longer rotation provides habitat for various species, including several endangered species, stores carbon on a long-term basis, and is key for improving water quality.

Various governmental and nongovernmental organizations are actively providing financial support for increasing the area under longleaf pine. America's Longleaf Restoration Initiative (ALRI) and Longleaf Alliance share a goal of expanding the longleaf pine area to 3.2 million hectares by 2025 (Guldin et al., 2016). About 33 organizations (nonprofits, state and federal agencies, industry, associations, and academia) are working together under the Longleaf Pine Partnership Council for increasing the area of longleaf pine in Southern United States. Federal programs like the Conservation Reserve Program
(CRP), Environmental Quality Incentive Program (EQIP), Wildlife Habitat Incentive Program (WHIP), and Conservation Stewardship Program (CSP) have effectively put longleaf pine in the limelight, especially in the Lower Coastal Plain physiography region (Stubbs, 2014). For example, CRP CP36 promotes longleaf pine plantations on the former crop, pastures, and hayfields and provides landowners a sizeable financial package with a signing bonus, cost share (up to $90 \%$ for expenses related to site preparation, seedlings, and planting), and a rental payment (\$86$\$ 160 /$ ha/year) to maintain longleaf plantation over a contract period (Stubbs, 2014).

Despite all the efforts to restore longleaf pine by various organizations, there is no net change in the area of longleaf pine plantations from the past 5 years based on a recent analysis using Forest Inventory and Analysis ${ }^{1}$. Longleaf pine forest cover type increased by 82,555 hectares between 2010 and 2015, but longleaf pine/oak forest type decreased by 84,579 ha in the same period, giving a net loss of about 2,000 ha in Southern United States (McIntyre et al., 2018).

While these estimates are concerning for restoring longleaf pine, it is difficult to overlook the fact that only a few studies have focused on the economics of longleaf pine relative to other southern pine species using a similar set of assumptions for informing private (family and commercial) landowners who own about $87 \%$ of forestlands in Southern United States (McIntyre et al., 2018). Mills and Stiff (2013) reported that longleaf pine yielded higher financial returns (about \$2,914/ha) than intensively managed loblolly pine, even at higher site indices when payments for pine straw raking and timber were included. An economic comparison made by Dickens et al. (2014) across several scenarios of loblolly and longleaf pines with and without income from pine straw raking found that a two-thin 45 -year rotation longleaf pine scenario with annual pine straw income using 4 and $6 \%$ real discount rates and average historical Timber-Mart South prices (1997-2013) had higher Land Expectation Values (LEVs) of \$2,813/ha and $\$ 1,151 /$ ha, respectively, whereas a two-thin 33-year rotation with and without any income from pine straw raking had LEVs of $\$ 1,749$ and $\$ 366 /$ ha, respectively. Johnsen et al. (2009) analyzed the economics of longleaf pine in the presence of payments for pine straw income and timber and found that returns were positive when the CRP covered the plantation establishment cost.

Only a handful of studies have analyzed the role of payment for ecosystem services on the profitability of longleaf pine and have compared the same with the profitability of other southern pines. Alavalapati et al. (2002) compared slash and longleaf pines with the same amenity benefits and timber prices with additional red-cockaded woodpecker (RCW) monetary incentive for longleaf pine over varying carbon prices. Incorporating RCW and carbon benefits did increase the monetary value for longleaf $(\$ 1,700 / \mathrm{ha})$ but failed to provide higher financial returns than slash pine $(\$ 2,400 / \mathrm{ha})$. While water yield has been part of longleaf pine growth and yield models, only Susaeta and Gong (2019) used water yield benefits with payments for

\footnotetext{
${ }^{1}$ https://www.fia.fs.fed.us/
} 
forest products and biodiversity for comparing profits across loblolly and longleaf pines and concluded that water yield benefits would provide higher benefits to landowners for both selected species, but it would still require incentives ranging from $\$ 235 /$ ha and $\$ 642 /$ ha over 15 years to switch from loblolly to longleaf pine plantations.

Only a few studies study base longleaf pine in the same system as other southern pines, and even fewer studies that focus on the integration of payments of roundwood products and ecosystem services (Alavalapati et al., 2002; Johnsen et al., 2009; Mills and Stiff, 2013; Susaeta and Gong, 2019). It is vital to study the economics of major pine species under the same set of assumptions for informing family forest landowners in Southern United States who own about $60 \%$ of total forestlands in the region (Wear and Greis, 2012). This study gains even more importance as longleaf pine is tolerant to environmental risks, yet financial risk for the same has not been contextualized in existing studies relative to other southern pine species. Hence, the objectives of this study are to understand the differences in the profitability of southern pines (longleaf, loblolly, and slash) in the presence of payments for forest products and environmental amenities and determine financial risks related to southern pines in the Lower Coastal Plain physiographic region. This study will feed into the current longleaf pine restoration initiatives for increasing the efficacy of financial resources in restoring longleaf pine in Southern United States. Additionally, this study will guide ongoing efforts that focus on markets for ecosystem services for optimally designing monetary incentives to increase the participation of private forest landowners, in general, and family forest landowners, in particular, toward longleaf restoration.

\section{MATERIALS AND METHODS}

\section{Study Area}

The Coastal Plain physiographic region in Southern United States is divided into Upper and Lower Coastal Plains (Figure 1; NRCS, 2019). This region was initially covered with natural longleaf pine stands but now is dominated by planted loblolly and slash pine stands. Restoration of longleaf pine in this region gains even more significance in the context of climate-change adaptation as incidences like seawater flooding, hurricane, the salinity of estuaries, and storm surge from extreme weather events increase every year (Wuebbles et al., 2017). Additionally, the majority of potential restoration areas (identified as significant geographic areas (SGAs) by organizations interested in longleaf restoration) are located in the Lower Coastal Plain physiographic region (McIntyre et al., 2018). Landowners and counties that fall within SGAs are prioritized over other regions under CRP, EQIP, WHIP, and CSP programs for longleaf pine restoration (Guldin et al., 2016). In addition, South Georgia has $45 \%$ of the current longleaf pine plantations, the largest area among all the Southern States (Miles, 2019). Therefore, this study focuses only on the Lower Coastal Plain physiographic region of South Georgia for developing a nuanced understanding of the economics of longleaf pine relative to other southern pines.

\section{Forest Management Scenarios}

We selected six scenarios for each species for developing a comprehensive understanding of the economics of longleaf pine relative to other pines across site indices, management regimes, and payment schemes (Table 1). Scenario 1 was selected as the baseline for Scenarios 2 and 3, whereas Scenario 4 was the baseline for Scenarios 5 and 6 . We raked pine straw only in Scenarios 4, 5, and 6. Baseline scenarios were used to distinguish positive net benefit associated with the "additionality" concept widely used for carbon offsets (Ruseva et al., 2017), i.e., net carbon sequestered relative to the baseline. Additionally, the selected scenarios were replicated for three site indices. We acknowledge that the selected site indices are not the only site indices for loblolly, slash, and longleaf pines; however, they represent a wide range of site indices commonly reported in the literature.

\section{Growth and Yield Model}

We used stand-level growth and yield models for selected pine species (Gonzalez-Benecke et al., 2012). Three roundwood products were defined based on diameter at breast height (dbh) and top diameter (td) of the stem (outside bark): sawtimber $(\mathrm{dbh}:>30.5 \mathrm{~cm}, \mathrm{td}: 20.3 \mathrm{~cm})$, chip-and-saw $(\mathrm{dbh}:>20.3$ and < $30.5 \mathrm{~cm}$, td: $15.3 \mathrm{~cm}$ ), and pulpwood (dbh: $>15.3$ and $<20.3 \mathrm{~cm}$, td: $5.1 \mathrm{~cm}$ ). Planting density at age 0 was 1,400 seedlings/ha for each species for comparison purposes. We selected three equivalent site indices for loblolly $(24.4,21.3$, and $18.2 \mathrm{~m})$, slash $(24.4,22.8$, and $19.8 \mathrm{~m})$, and longleaf $(18.2,15.2$, and $13.7 \mathrm{~m}$ ) based on the average height $(\mathrm{m})$ at the base stand age of 25 years for all the species (Table 2).

\section{Water Yield Estimation}

We used the relationship of water yield as a function of management strategy, stand structure, and ecosystem water proposed by McLaughlin et al. (2013) for determining water yield values. Water yield $(\mathrm{mm})$ can be defined as:

$$
\begin{aligned}
W & =\left(1-\frac{E T}{P P T}\right) M P \\
\frac{E T}{P P T} & =0.0405 L A I+0.56
\end{aligned}
$$

where ET/PPT is the ratio between evapotranspiration (ET) and precipitation (PPT), MP is the mean annual precipitation ( $\mathrm{mm})$, and LAI is the leaf area index. Similarities exist across southern pines for water use, transpiration rate, and hydraulic conductance (Samuelson et al., 2012). We used a generalized relationship between ET/PPT and LAI (Figure 2) for all the species. This relationship was based on the data summarized for loblolly, longleaf, and slash pines by McLaughlin et al. (2013).

For determining LAI for loblolly and slash pines, we used the model reported in Gonzalez-Benecke et al. (2012). LAI was defined as a function of the Stand Density Index and SI (m), while SDI was defined as a function of Basal Area (BA, m²/ha) and the number of live trees/ha. We determined LAI for longleaf pine using the model developed by Gonzalez-Benecke et al. (2015), where LAI is a product of foliage biomass and the specific 


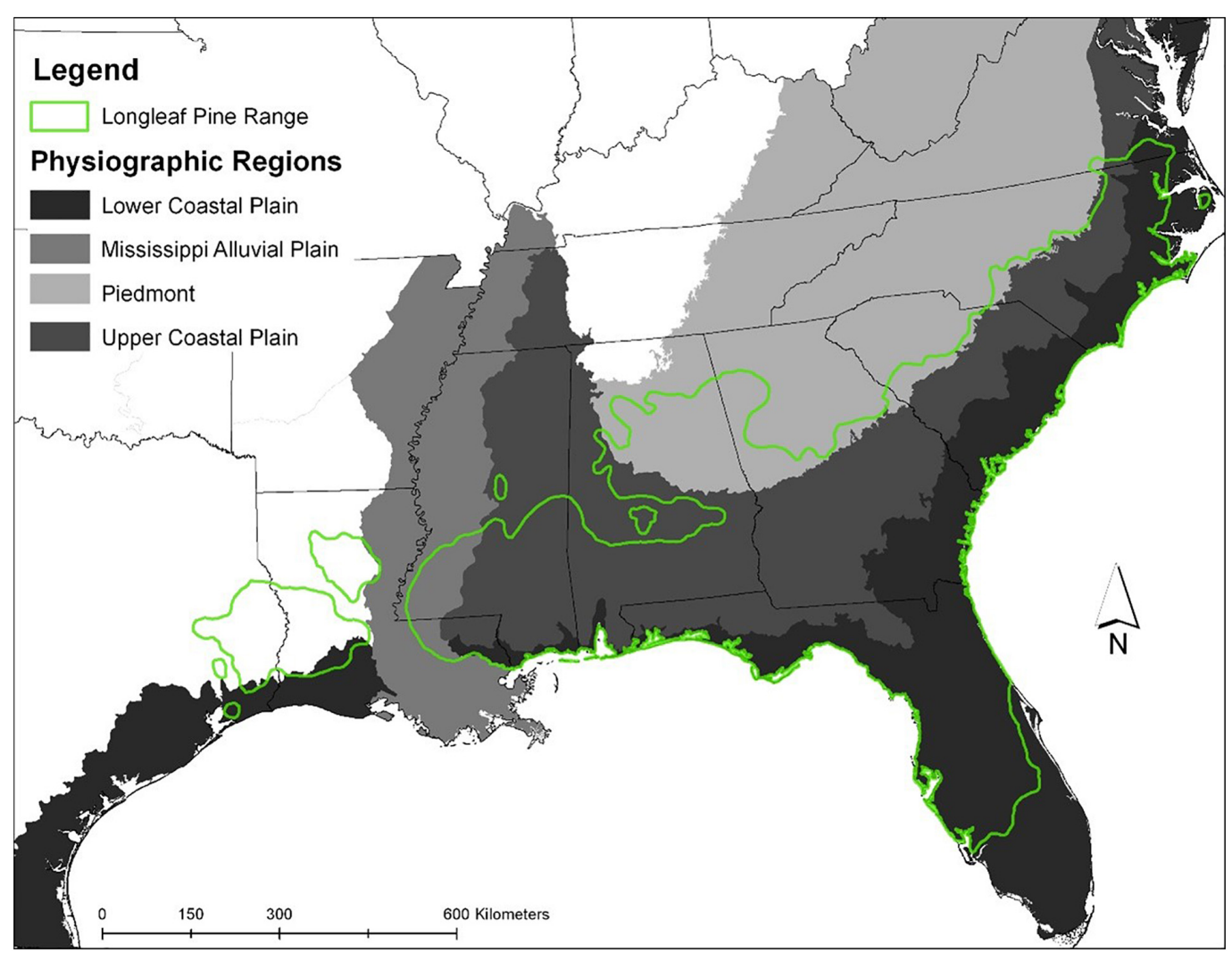

FIGURE 1| Physiogrpahic regions and longleaf pine range in the Southern United States (NRCS, 2019).

TABLE 1 | Scenarios selected for the analysis in the study.

\begin{tabular}{|c|c|c|c|c|c|c|}
\hline Scenario & Reference scenario & Timber & Hunting & Pine straw & Carbon & Water \\
\hline S1 & - & Yes & Yes & No & No & No \\
\hline S2 & S1 & Yes & Yes & No & Yes & No \\
\hline S3 & $\mathrm{S} 1$ & Yes & Yes & No & Yes & Yes \\
\hline S4 & - & Yes & Yes & Yes & No & No \\
\hline S5 & S4 & Yes & Yes & Yes & Yes & No \\
\hline S6 & S4 & Yes & Yes & Yes & Yes & Yes \\
\hline
\end{tabular}

The reference scenario is used as the baseline for estimating net carbon stored and net water yield.

needle area (SNA, $\mathrm{m}^{2} / \mathrm{kg}$ ). Table 3 shows the parameters and relationships used for each species for modeling LAI.

\section{Economic Modeling}

Hartman (1976) extended the original Faustmann (1995) Model to include the ecosystem values associated with the standing forest stand in addition to timber benefits. This study extends the Hartman Model by including payments for net carbon stored and net water yield. The forestland value is determined using Eq. 3:

$$
L E V_{t}=\frac{p v c(t)+p v w(t)+p v t(t)-p v m(t)}{1-e^{-r t}}
$$

where $\operatorname{LEV}(\$ / \mathrm{ha})$ is the present value of profit at a given rotation age $(t)$ over perpetuity, $\operatorname{pvc}(t)$ is the present value of net additional sequestered carbon benefit $(\$ / h a), \operatorname{pvw}(t)$ is the present value of net water yield $(\$ / h a), \operatorname{pvt}(t)$ is the present value $(\$ / h a)$ of timber benefits (annual hunting lease, thinned biomass, standing timber), $\operatorname{pvm}(\mathrm{t})$ is the present value (\$/ha) of management costs (mechanical and chemical site preparation, weed control, fertilization, and tax), and $r$ is the real discount rate. LEV assumes that the values of all costs and revenues are identical for all the rotations and are compounded to the end of the rotation to get the future value (Ruseva et al., 2017). Therefore, it represents the maximum amount to buy bare land at the beginning of a forest rotation, which helps to make a reasonable comparison between loblolly, longleaf, and slash pine plantations. It is assumed that timber harvested at the optimal rotation age (at rotation age at which LEV maximizes) remains in the finished wood products. As a result, we have not accounted for the carbon penalty at the time of clear-cutting. 
TABLE 2 | Silvicultural treatments for selected scenarios at different years for loblolly, slash, and longleaf pines.

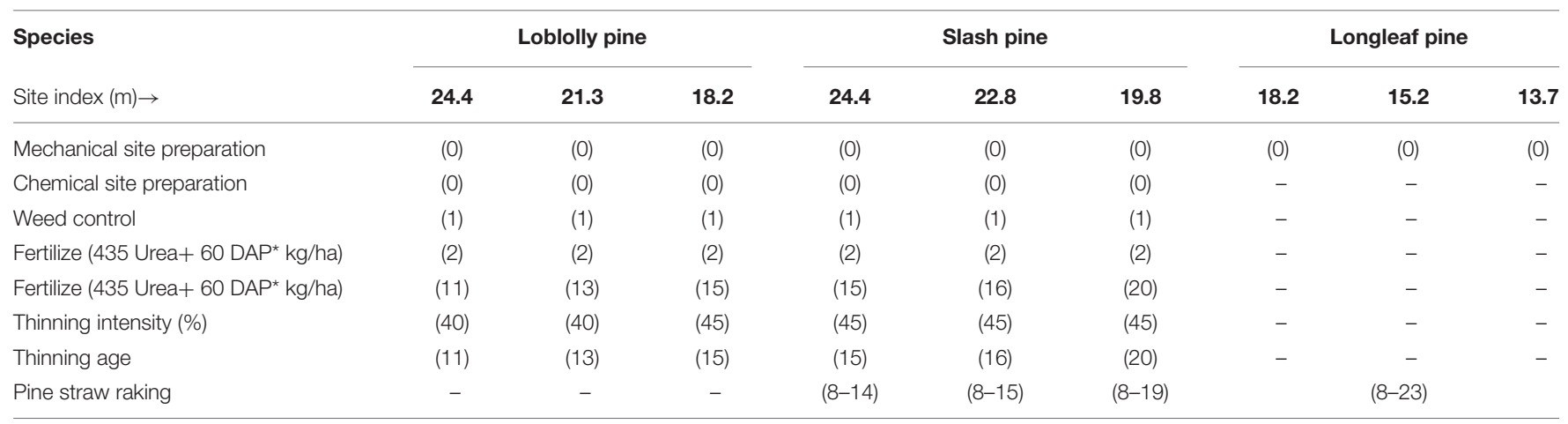

${ }^{*}$ DAP-Diammonium Phosphate $\left(18 \% \mathrm{~N}, 46 \% \mathrm{P}_{2} \mathrm{O}_{5}\right)$.

Site Index is based on the average height $(m)$ at the base stand age of 25 years for all the species. The value reported in parenthesis is stand age in years. The thinning age was determined when the total weight of the removed biomass reached at least $62 \mathrm{t} / \mathrm{ha}$, the basal area reached 27-35 $\mathrm{m}^{2} / \mathrm{ha}$, and QMD (quadratic mean diameter) was $\geq 15.5 \mathrm{~cm}$ (Harrington, 2001; Dickens et al., 2003). The thinning intensity was based on the residual basal area of $18.2 \mathrm{~m}^{2} /$ ha. Fertilization volume and applications are as per the productivity of sandy soils in the Lower Coastal Plain (Dickens et al., 2012). Longleaf, slash, and loblolly pine stands that are suitable for raking pine straw are commonly raked starting canopy closure until the first thinning (Dickens et al., 2012). Hence, pine straw raking started from year eight until the first thinning age for slash pine and until canopy closure age for longleaf pine. We used Gonzalez-Benecke et al. (2015) for estimating annual needle fall and pine straw yields for slash and longleaf pines. Gonzalez-Benecke et al. (2015) does not allow for fertilizer application for longleaf pine management (around eight years old) when they are managed intensively for pine straw management.

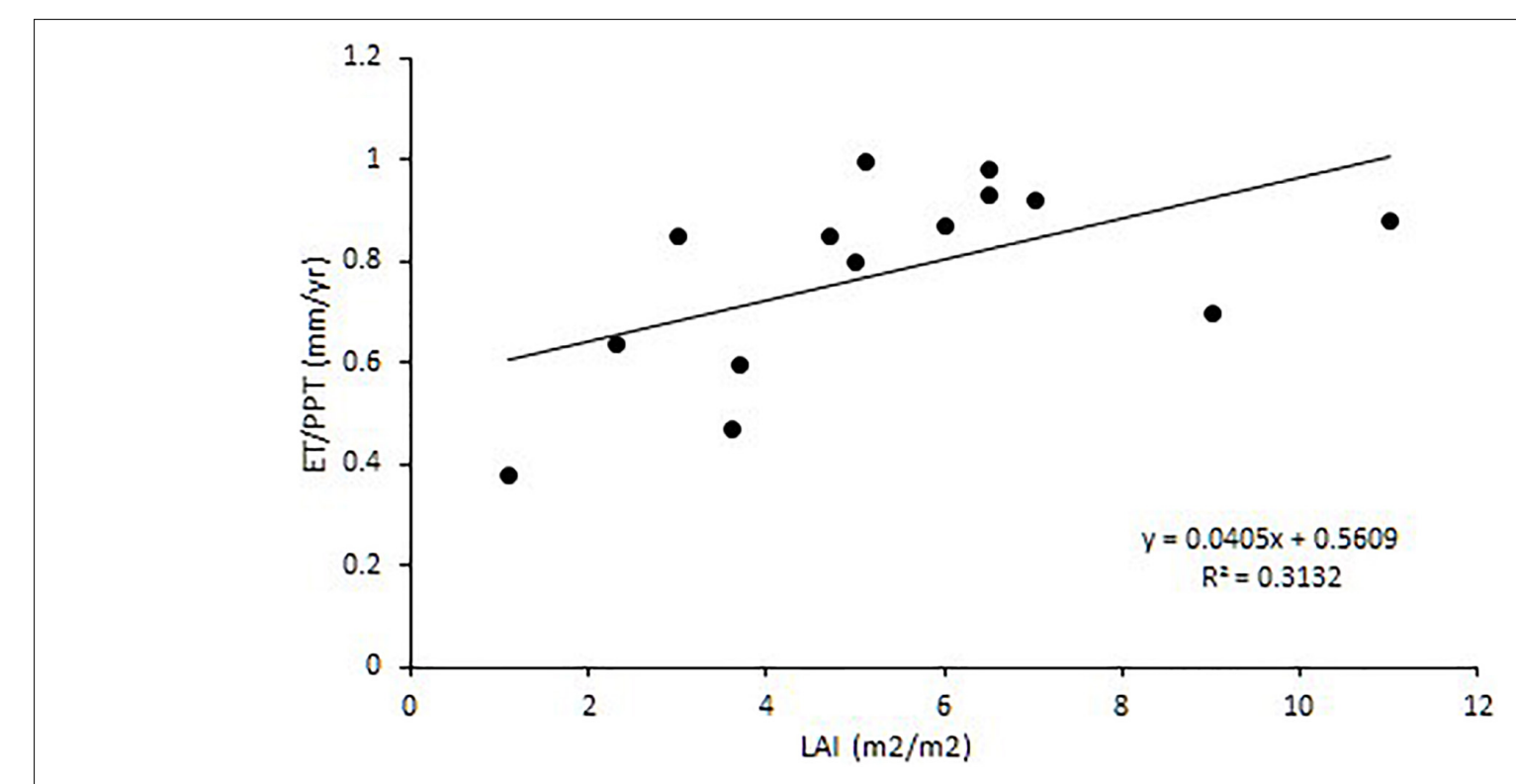

FIGURE 2 | Ratio of evapotranspiration by precipitation as a function of Stand Leaf Area Index (LAl) across the Southern United States (McLaughlin et al., 2013).

We used the 2020 Q1 southwide average stumpage prices for sawtimber $(\$ 21.4 / t)$, chip-and-saw $(\$ 15.7 / t)$, and pulpwood $(\$ 9.9 / \mathrm{t})$ from the Timber-Mart South (TMS, 2020). We obtained costs related to various silvicultural treatments (Table 4) from Maggard and Barlow (2018). Pine straw suppliers and retailers usually prefer species with long needles like longleaf and slash pines that grow between 16 and $45 \mathrm{~cm}$ in comparison to smaller loblolly pine needles that typically grow between 13 and $22 \mathrm{~cm}$ (Dickens et al., 2014). Hence, we included the income from pine straw raking for longleaf $(\$ 142 / \mathrm{ha})$ and slash $(\$ 66.37 / \mathrm{ha})$ pines in our economic analysis (Dickens et al., 2012). Pine straw prices were determined based on payments to the forest landowners. We acknowledge that pine straw raking on a loblolly pine stand is not very common in the study area and hence was not included in the analysis.

The real discount rate was $5 \%$, reflecting the range between 5 and $7 \%$ commonly used for assessing forest investments in the Southern United States (Conrad and Joseph, 2018). Income from hunting lease is $\$ 29 / \mathrm{ha} / \mathrm{yr}$ (Mingie and Mengak, 2014), and the $\operatorname{tax}$ is $\$ 12 / \mathrm{ha} / \mathrm{yr}^{2}$. We used the price of pumping groundwater from aquifers in South Georgia, i.e., $\$ 0.071 / \mathrm{kL}$ (Burgess et al., 2017), as a proxy for the price of the unit of water flowing through pine plantations. The price of carbon $(\$ 18.7 / \mathrm{t} \mathrm{C})$ is the average price paid for forestry and land-use projects in voluntary carbon

${ }^{2}$ www.timbertax.org 
markets in 2017 (Hamrick and Gallant, 2017). We considered the aboveground (needles, branches, stem, bark, forest floor, and understory) and belowground (tap, coarse and fine roots) carbon stored in standing trees for the analysis.

\section{Financial Risk and Sensitivity Analyses}

The profitability of growing each pine species is based on expected cash flows that are inherently uncertain in nature. Uncertainties associated with timber prices are due to weather, competition, and policy changes, as well as the development of new technologies (Prestemon and Abt, 2002). Along with forest products, carbon credits were found to range between less than $\$ 1$ and \$126/t (World-Bank and ECOFYS, 2017). Similarly, water prices varied considerably from region to region (Walton, 2010). Therefore, we performed sensitivity and risk analyses by simultaneously changing the current prices of the sawtimber, chip-n-saw, pulpwood, hunting lease, pine straw, carbon, and

TABLE 3 | Parameters used for determining leaf area index for loblolly, slash, and longleaf pines.

\begin{tabular}{|c|c|c|}
\hline Species & $\beta_{0}, \beta_{1}$, and $\beta_{2}$ & Model \\
\hline Loblolly/ Slash & LAl & $\beta_{0} /\left(1+\mathrm{e}^{-\left(\left(\mathrm{SDI}-\beta_{2}\right) / \beta_{1}\right)}\right.$ \\
\hline Loblolly & 0 & $-2.0287+0.1966^{*} \mathrm{SI}$ \\
\hline Slash & 0 & $-1.307+0.47^{\star} \mathrm{SI}$ \\
\hline Loblolly/Slash & 1 & $12.095+2.586^{*} \mathrm{SI}$ \\
\hline Loblolly/Slash & 2 & $327.234 /\left(1+(\mathrm{SI} / 18.571)^{-4.929}\right)$ \\
\hline \multirow[t]{2}{*}{ Longleaf } & Foliage Biomass & 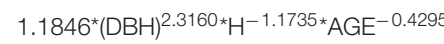 \\
\hline & SNA & $2.8172+1.3218^{\star} e^{(-0.0366 * A G E)}$ \\
\hline
\end{tabular}

Units for Leaf Area Index (LAl) in $\mathrm{m}^{2} / \mathrm{m}^{2}$. SDI: Reineke's Stand Density Index in metric units. Sl: Site Index (m). AGE: age of stand in years. H: Total height (m). Foliage Biomass (kg/tree). SNA: Specific Needle Area $\left(\mathrm{m}^{2} / \mathrm{kg}\right)$.

TABLE 4 | Parameters used for estimating costs and incomes for the management of selected pine species.

\begin{tabular}{lll}
\hline Treatment \& income sources & Price & Species \\
\hline Mechanical site preparation & $\$ 255.5 / \mathrm{ha}$ & All \\
Chemical site preparation & $\$ 191.8 / \mathrm{ha}$ & Loblolly/ Slash \\
Planting & $\$ 214.4 / \mathrm{ha}$ & All \\
Herbaceous weed control & $\$ 141.12 / \mathrm{ha}$ & Loblolly/ Slash \\
Management cost & $\$ 12.35 / \mathrm{ha} / \mathrm{yr}$ & All \\
Tax & $\$ 12.35 / \mathrm{ha} / \mathrm{yr}$ & All \\
Fertilization (DAP) & $\$ 0.55 / \mathrm{kg}$ & Loblolly/ Slash \\
Fertilization (Urea) & $\$ 0.54 / \mathrm{kg}$ & Loblolly/ Slash \\
Fertilization application & $\$ 0.26 / \mathrm{kg}$ & Loblolly/ Slash \\
Seedling & $\$ 149.5 / \mathrm{ha}$ & Loblolly/ Slash \\
Seedling & $\$ 370 / \mathrm{ha}$ & Longleaf \\
Pine straw & $\$ 66.37 / \mathrm{t}$ & Slash \\
Pine straw & $\$ 142 / \mathrm{t}$ & Longleaf \\
Carbon & $\$ 18.7 / \mathrm{t} \mathrm{C}$ & All \\
Water & $\$ 0.07 / \mathrm{kL}$ & All
\end{tabular}

Treatment type and application year are listed in Table 2 for each pine species. Pine straw collection year for each species is also listed in Table 2. We converted the price of a metric ton of carbon dioxide $\left(\$ 5.1 / t \mathrm{CO}_{2}\right)$ into a metric ton of carbon by multiplying by $44 / 12$. water by $\pm 10 \%$ for ascertaining their impact on the LEVs. Similarly, we simultaneously changed the current prices of all silviculture-related costs by $\pm 10 \%$ for ascertaining their effects on the LEVs. The effect of changes in the real discount rates was also analyzed using $\pm 10 \%$ change. We used MS Excel with the assistance of @RISK 6.3.1 software $^{3}$ for undertaking sensitivity and risk analyses. The software uses a stochastic Monte Carlo simulation procedure for conducting sensitivity and risk analyses where input variables vary simultaneously to produce the output variables. We simulated the developed model 1000 times and used a triangular probability distribution function for input variables (Simoes et al., 2016). Triangular distribution has a central peak, which represents the most likely value, and endpoints represent the minimum and maximum values. This distribution is commonly used when there is not much historical information that can be used for ascertaining the probability distributions of the variables (Simoes et al., 2016).

\section{RESULTS}

\section{Productivity Assessment}

The Mean Annual Increment (MAI) for all species increased with the increase in the site index (Figure 3). MAI for loblolly was higher than the slash and longleaf pines. MAI of longleaf pine, on average, was $68 \%$ lower than loblolly pine and $38 \%$ lower than slash pine across site indices. MAI of slash pine, on average, was $28 \%$ lower than loblolly pine.

\section{Economics Without Pine Straw Income}

Scenario 1: The LEV of loblolly pine was highest across all the site indices (Table 5). The LEV for loblolly pine ranged between $\$ 1.804 /$ ha and $\$ 4,598 /$ ha, between $\$ 911 /$ ha and $\$ 2,778 /$ ha for slash pine, and between $\$-460 /$ ha and $-\$ 27 /$ ha for longleaf pine. The LEVs were negative for longleaf pine across all site indices. The optimal rotation age ranged between 20 and 24 years for loblolly pine, 26 and 30 years for slash pine, and 40 and 46 years for longleaf pine. We noticed that a negative relationship exists between optimal rotation age and the site index, i.e., higher site indices have a lower rotation age and vice versa. We also noticed that a negative relationship exists between optimal rotation age and the highest LEV, i.e., lower rotation ages have higher LEVs and vice versa.

Scenario 2: Similar to Scenario 1, loblolly pine outperformed longleaf and slash pines based on income from forest products, hunting lease, and carbon across all site indices (Table 5). The highest LEV was $\$ 4,633 /$ ha for loblolly pine at SI $24.4 \mathrm{~m}$. Income from net sequestered carbon increased the LEV by $1 \%$ for loblolly pine, $5 \%$ for slash pine, and $12 \%$ for longleaf pine relative to Scenario 1. Rotation ages also increased for all site indices and all species relative to Scenario 1 .

Scenario 3: Loblolly pine still had the highest LEV of $\$ 4,625 /$ ha among all species when incomes from forest products, hunting lease, carbon, and water yield were considered (Table 5). The LEVs of loblolly pine were, on average, \$1,157/ha higher

\footnotetext{
${ }^{3}$ https://www.palisade.com/
} 


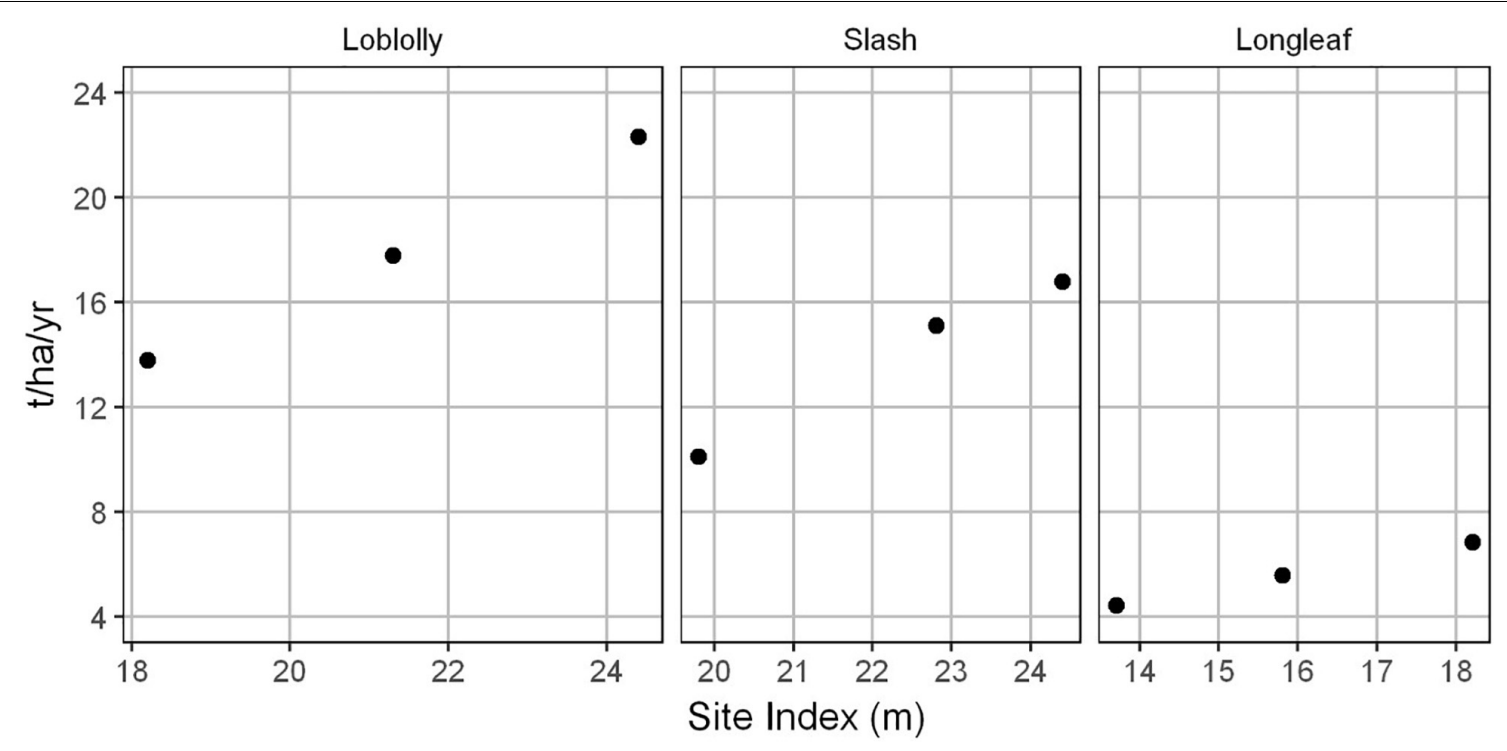

FIGURE 3 | Mean Annual Increment (MAI) for loblolly, slash, and longleaf pines relative to the respective site indices. Site Index is based on the average height (m) at the base stand age of 25 years for all the species.

than slash pine, while longleaf pine made a profit of only $\$ 1 /$ ha. Income from water yield decreased LEV by $0.2 \%$ for loblolly pine, $0.7 \%$ for slash pine, and $10 \%$ for longleaf pine relative to Scenario 2. Rotation age also remained consistent for loblolly pine and decreased by a year for slash pine and decreased by 2 years for longleaf pine for the site indices relative to Scenario 2.

Hence, the LEV was highest for loblolly pine after considering incomes from forest products, hunting lease, net carbon stored, and net water yield with a shorter rotation age. A detailed breakdown of the contribution of each of the income and costs toward LEVs is reported in Supplementary Figure 1. Total carbon stored and water yields at optimal rotation ages are also reported in Supplementary Table 1. The addition of income from net carbon increased the LEV and optimal rotation age for all the species. The addition of income from net water yield decreased the LEV for all the species with very less effect on the optimal rotation age.

TABLE 5 | Land expectation values for loblolly, slash, and longleaf pines across site indices without income from pine straw raking.

\begin{tabular}{ccccc}
\hline Species & SI (m) & Scenario $\mathbf{1}(\mathbf{\$} / \mathbf{h a})$ & Scenario 2 (\$/ha) & Scenario 3 (\$/ha) \\
\hline Loblolly & 24.4 & $4,598(20)$ & $4,633(21)$ & $4,625(21)$ \\
& 21.3 & $3,079(22)$ & $3,096(23)$ & $3,092(23)$ \\
\multirow{4}{*}{ Slash } & 18.2 & $1,804(24)$ & $1,815(25)$ & $1,813(25)$ \\
& 24.4 & $2,778(26)$ & $2,908(29)$ & $2,887(28)$ \\
& 22.8 & $2,101(27)$ & $2,199(30)$ & $2,187(29)$ \\
\multirow{4}{*}{ Longleaf } & 19.8 & $911(30)$ & $993(33)$ & $984(32)$ \\
& 18.2 & $-27(40)$ & $13(44)$ & $1(46)$ \\
& 15.2 & $-267(42)$ & $-234(47)$ & $-240(46)$ \\
& 13.7 & $-460(46)$ & $-447(50)$ & $-494(50)$ \\
\hline
\end{tabular}

The value reported in parenthesis is rotation age (years) for the respective scenario.

\section{Economics With Income From Pine Straw}

Scenario 4: Based on incomes from forest products, hunting lease, and pine straw, slash pine had the highest LEV of $\$ 5,505 /$ ha at SI $24.4 \mathrm{~m}$. The rotation age for slash pine ranged between 24 and 27 years (Table 6). While LEV was higher for slash pine, rotation age was shorter for longleaf pine with 23 years. Income from pine straw was profitable for longleaf pine along with shorter rotation ages across all site indices relative to Scenarios 1 , 2, and 3. The LEV increased by $145 \%$ for slash pine, and almost $1225 \%$ for longleaf pine relative to Scenario 1, showing the relative importance of pine straw income for the profitability of longleaf pine.

Scenario 5: When considering income from pine straw raking along with incomes from forest products, hunting lease, and net stored carbon, the highest LEV and shortest rotation age was observed for slash pine at SI $24.4 \mathrm{~m}$ (Table 6). The LEVs, on average, increased by $\$ 178 /$ ha for slash pine and $\$ 509 /$ ha for longleaf pine relative to Scenario 4 .

TABLE 6 | Land expectation values for loblolly, slash, and longleaf pines across site indices with income from pine straw raking.

\begin{tabular}{lcccc} 
Species & SI (m) & Scenario 4 (\$/ha) & Scenario 5 (\$/ha) & Scenario 6 (\$/ha) \\
\hline Slash & 24.4 & $5,505(24)$ & $5,694(27)$ & $5,656(27)$ \\
& 22.8 & $4,852(24)$ & $5,076(27)$ & $5,042(27)$ \\
& 19.8 & $3,806(27)$ & $3,930(30)$ & $3,913(29)$ \\
Longleaf & 18.2 & $3,754(23)$ & $3,846(29)$ & $3,793(29)$ \\
& 15.2 & $2,799(23)$ & $2,873(32)$ & $2,826(29)$ \\
& 13.7 & $1,936(23)$ & $3,299(38)$ & $3,254(38)$ \\
\hline
\end{tabular}

The value reported in parenthesis is rotation age (years) for the respective scenario. 


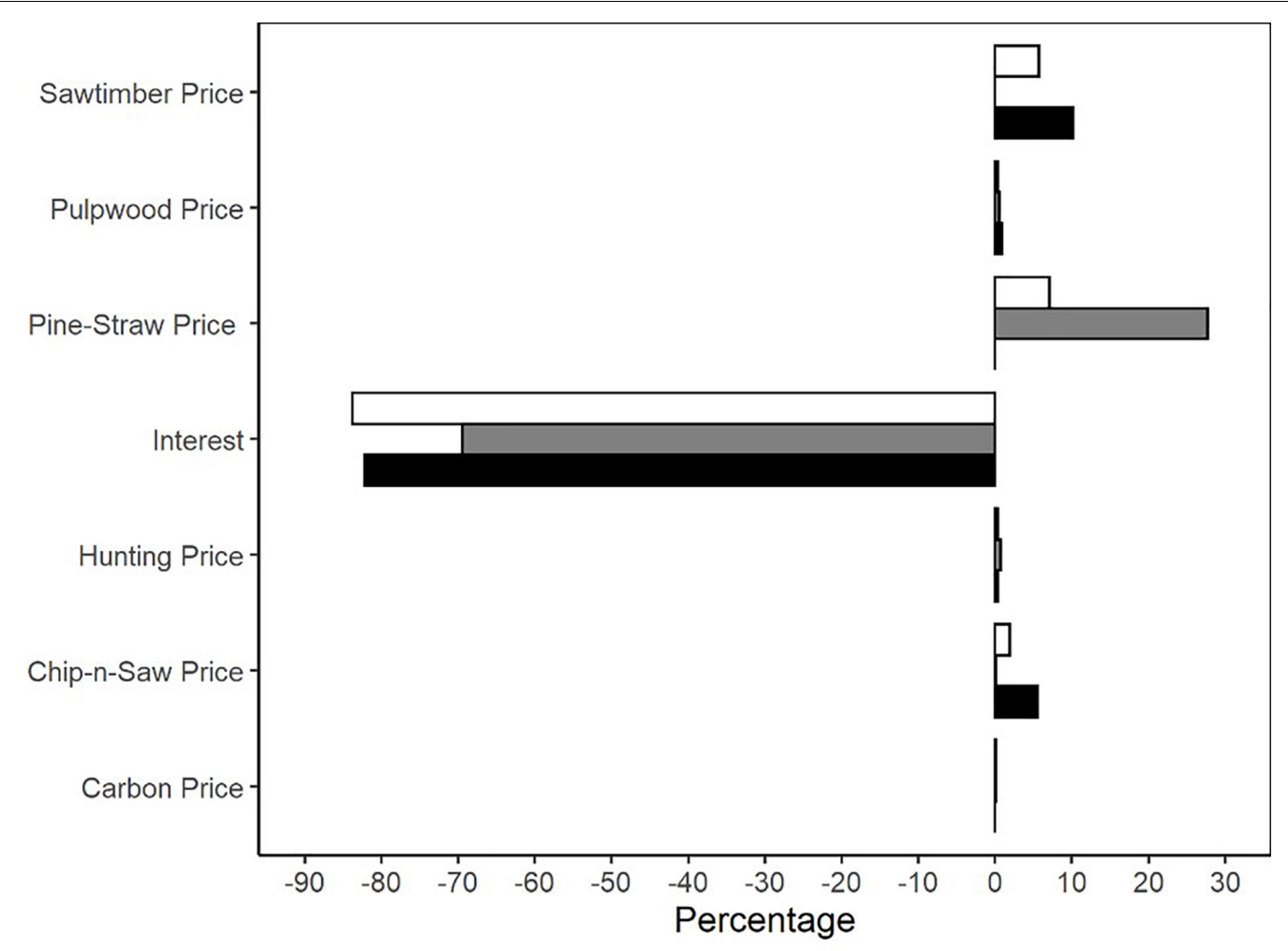

Loblolly $\square$ Longleaf $\square$ Slash

FIGURE 4 | Contribution of input variables to the variance of simulated LEV $(n=1,000)$ for loblolly, slash, and longleaf pines.

Scenario 6: The highest LEV and shortest rotation age were observed for slash pine at SI $24.4 \mathrm{~m}$ when considering incomes from forest products, hunting lease, net stored carbon, and net water yield. The LEV, on average, was lower by $\$ \$ 29 /$ ha for slash pine and $\$ 48 /$ ha for longleaf pine than Scenario 5.

Hence, LEV for slash pine was highest after considering incomes from forest products, hunting lease, net carbon stored, pine straw, and net water yield. The shortest rotation age was observed for longleaf pine when only income from forest products, hunting lease, and pine straw was considered. However, with addition of net stored carbon and net water yield, the shortest rotation age was for slash pine. The highest percentage increase in LEV was observed for longleaf pine (1225\%) with the inclusion of pine straw income. A detailed breakdown of the contribution of each of the income and costs toward LEVs is reported in Supplementary Figure 2. Total carbon stored and water yields at optimal rotation ages are also reported in Supplementary Table 2.

\section{Financial Risk and Sensitivity Analyses}

We selected Scenario 3 for loblolly pine and Scenario 6 for slash and longleaf pines at the highest site index for sensitivity and risk analyses. We used the contribution of variance output to analyze the effective change in LEV with a certain percentage of change in the income and costs (inputs). Contribution of variance used stepwise regression where input variables entered into the regression model sequentially in an iterative process. If the input was not significant or was highly correlated in the stepwise regression process, it was dropped from the regression model. Only significant variables remained in the regression model at the end of the iterative process. Stepwise regression was followed by forward regression. Variables (present in the finalized stepwise regression) entered forward regression in the same order as in stepwise regression. With the addition of each variable in forward regression, change in $\mathrm{R}^{2}$ was recorded as the additional variables' percentage contribution to the total variance in LEV. Hence, the interpretation of the output in Figure $\mathbf{4}$ was similar to any regression model outputs.

Among the input variables, only variables reported in Figure 4 contributed significantly to the LEV. The discount rate negatively contributed to the variation in the LEV, while prices for pine straw, carbon, hunting lease, pulpwood, chip-n-saw, and sawtimber contributed positively (Figure 4). Pulpwood and chipn-saw prices were important for determining the LEV of loblolly and slash pines, whereas chip-n-saw price was important for lo pine. The highest variation of the LEV with interest rate was observed for slash pine $(-84 \%)$, and the lowest was observed for longleaf pine (-70\%). Negligible changes were observed for slash and loblolly pines with varying pine straw prices, but a $1 \%$ change 


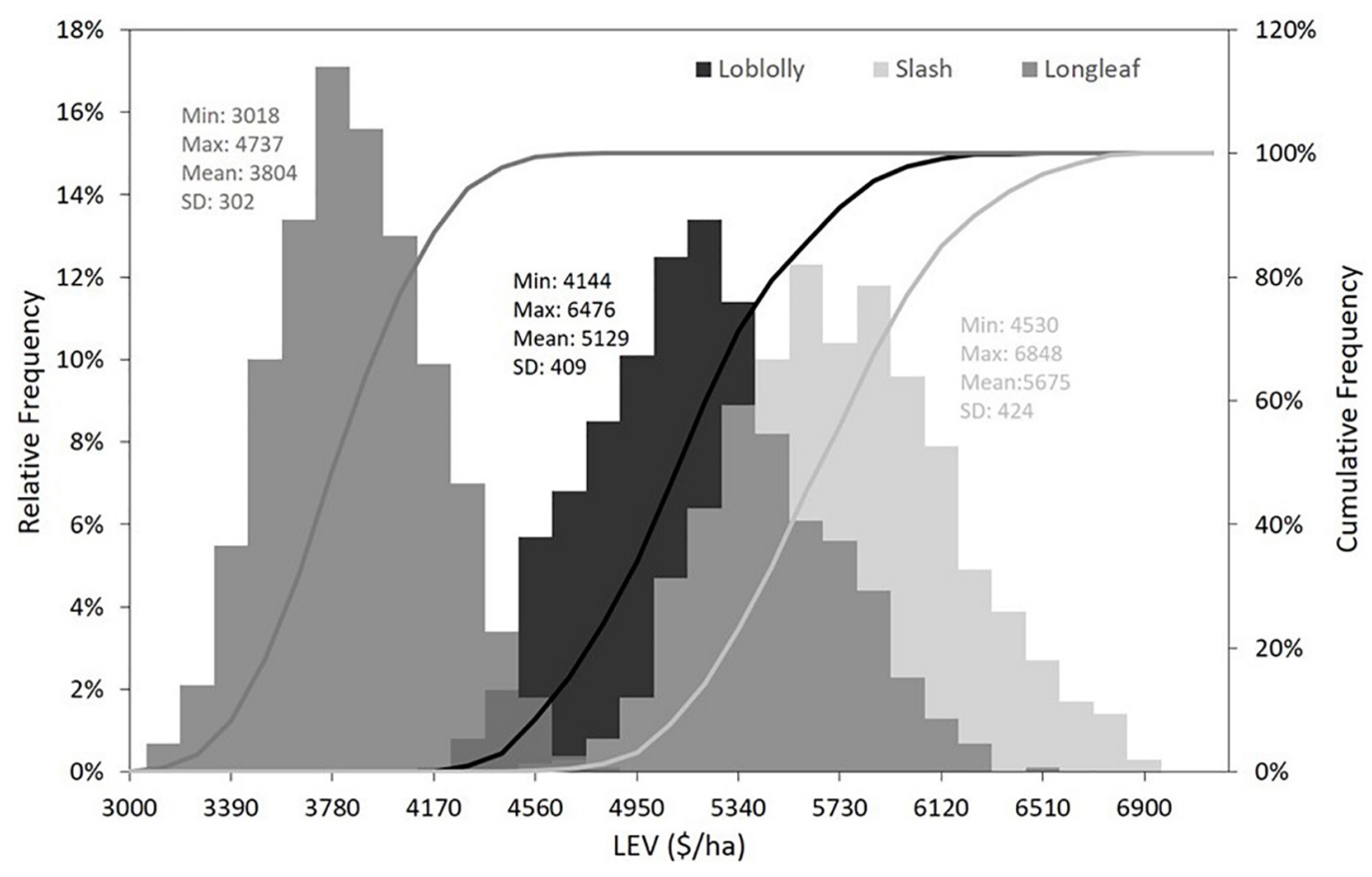

FIGURE 5 | Relative distribution and cumulative frequency distribution of simulated LEVs of loblolly, slash, and longleaf pines.

in longleaf pine straw price explained a $+28 \%$ variance in the LEV. Carbon and water prices were insignificant in determining the variance of LEVs.

The standard deviation of simulated LEVs for slash and loblolly pines was larger than that for longleaf pine, suggesting lower financial risks for longleaf pine (Figure 5). Overall, slash pine provided higher profits, whereas profits related to longleaf pine were lower; however, higher financial risks were associated with loblolly and slash pines than longleaf pine.

\section{DISCUSSION}

Longleaf pine is better suited for expected changes in climate and protection of the endangered species in Southern United States (Stanturf et al., 2007; Samuelson et al., 2012). Currently, several governmental and nongovernmental organizations are promoting various programs for increasing acreage under longleaf pine, yet family forest landowners lack reliable comparative economic analysis across the major southern pine species (McIntyre et al., 2018). This study uses a common system boundary and a similar set of assumptions for assessing the profitability of loblolly, slash, and longleaf pines across various site indices and silvicultural regimes with and without payments for environmental amenities, thereby providing a platform for family forest landowners for informed decision making.

The income from pine straw raking increased LEV 145\% for slash pine, and almost $1225 \%$ for longleaf pine while still showing lower LEVs for longleaf pine. Income from pine straw has been considered a major driving factor for landowners to plant longleaf pine and adding pine straw has greatly improved the financial performance of longleaf pine plantations (Mills and Stiff, 2013). However, several factors have indicated that longleaf pine may perform better than loblolly pine than that shown in our analysis. Mills and Stiff (2013) considered a higher site index than our study and included income from poles at the same discount rate and found longleaf pine to be more profitable than loblolly pine at equivalent site indices. Johnson (2011) points to the evidence that average timber sale prices were $10-20 \%$ higher when species composition was primarily longleaf pine. Taylor and Foster (2004) state that pine straw can be harvested on marginal or poor-quality forest acreage or sites unsuitable for wood fiber products, and longleaf pine with higher quality straw can yield much higher rates. In addition, pine straw accounted for more than $16 \%$ of the forest product market, with a more robust market predicted to be available in South Georgia (Dyer et al., 2012). Therefore, competitive pine straw markets and increasing share of pine straw in the forest markets make longleaf pine economically reliable than other southern pines in the region.

Considering only income from roundwood products, Mills and Stiff (2013) reported an LEV of $\$ 1,508 /$ ha for loblolly pine at SI $19.8 \mathrm{~m}$. Similarly, Siry (2002) reported the LEV of $\$ 3,486 /$ ha with rotation age 25 years at a $6 \%$ discount rate for loblolly pine (SI $18.3 \mathrm{~m}$ ). Our LEV for loblolly pine when considering incomes from roundwood products and hunting lease income range at SI $18.2 \mathrm{~m}$ was $\$ 1,804 /$ ha with rotation age 24 years. In our study, LEVs for slash pine without any income from pine straw raking ranged between $\$ 911$ and $\$ 2,77 /$ ha with rotation ages between 26 and 30 years. Alavalapati et al. (2002) reported LEV of $\$ 2,830 /$ ha for slash pine at the rotation age of 30 years using a $5 \%$ discount rate while accounting for income from roundwood 
products. These differences for slash and loblolly pines could be ascribed to current lower prices of sawtimber, as in the early 2000 s, the sawtimber prices were $\$ 48 / \mathrm{t}$ while we used a value of $\$ 21.4 / \mathrm{t}$ in our study.

LEVs increase and rotation ages decrease with a rise in the site index. Relatively low site productivity results in low profitability, and hence landowners wait longer to get maximum output, whereas higher site indices reach maximum productivity at an earlier age (Nakajima et al., 2017). LEVs with income from forest products, hunting lease, and pine straw ranged between $\$ 1,936 /$ ha and $\$ 3,754 /$ ha with rotation age 23 years for longleaf pine in our study. Johnson (2011) reported values with timber and pine straw income between $\$ 1,191 /$ ha and $\$ 2,208 /$ ha at discount rates 6 and 4.5\%, respectively, while Mills and Stiff (2013) reported values between $\$ 440 /$ ha and $\$ 1,465 /$ ha at lower site indices and between $\$ 1,474 /$ ha and $\$ 2,793 /$ ha at higher site indices at a $5 \%$ discount rate for longleaf pine plantations. The rotation age used by Mills and Stiff (2013) was between 42 and 52 years, while Johnson (2011) used a rotation cycle of 45 years. The LEV reported in our study is slightly higher than other studies, and our rotation age is shorter. This can be ascribed to historically higher pine straw and lower sawtimber prices.

The rotation age increased across all the scenarios when net stored carbon was considered, along with income from pine straw, forest products, and hunting lease. This was expected as, with a rise in stand age, the carbon accumulated also increases. As the stand grows, carbon accumulates in the stand, and so does the value of stand carbon. Recent studies have shown that loblolly pine will grow more wood than slash and longleaf pine on different soils (Zhao et al., 2012). Gibson et al. (2007) concluded that slash pine had $4-11 \%$ greater density and $4 \%$ less moisture content than loblolly pine growing in the same soil. These characteristics can be attributed to a higher increase in income for slash pine than loblolly pine in Scenario 2 when income from net carbon was considered in the study.

The addition of water yield income overall reduced LEVs across all pine species and site indices. Higher stand age classes have lower water yield for similar silvicultural practices (Sun et al., 2015). Therefore, when the payment for net water yield was added in the analysis in the presence of payment for net carbon sequestered, the LEV decreased relative to Scenarios 1 and 4 (baseline). In the baseline scenarios, water yields were relatively higher due to shorter optimal rotation ages.

Susaeta and Gong (2019) reported LEVs that ranged between $\$ 2,352 /$ ha and $\$ 11,195 /$ ha for loblolly pine with water yield, timber, and wildlife income, while Glenn (2012) reported values that ranged between $\$ 1,143 /$ ha and $\$ 1,494 /$ ha when considering income from timber and wildlife. Our LEVs for loblolly pine with timber, hunting lease, net stored carbon, and water yield income ranged between $\$ 1,813$ and $\$ 4,6259 /$ ha with rotation age ranging between 21 and 25 years. Similarly, along with income from forest products, hunting lease, net carbon and water yield, and slash pine with income from pine straw raking, LEVs ranged between $\$ 3,913$ and $\$ 5,656 /$ ha while they ranged between $\$ 984 /$ ha and $\$ 2,887 /$ ha without any income from pine straw raking. LEVs reported with water yield and timber income by Susaeta et al. (2016) for slash pine were between $\$ 1,472 /$ ha and $\$ 8,831 /$ ha.
LEVs reported in our study for longleaf pine with forest products and environmental amenities together with pine straw ranged between $\$ 3,254$ and $\$ 3,793 /$ ha, while without pine straw, they ranged between $-\$ 494$ and $-\$ 1 /$ ha. Our results are within the range reported by Susaeta and Gong (2019), with LEVs ranging from $\$ 1,724$ to $\$ 9,807 /$ ha when considering incomes from pine straw, water yield, wildlife, and timber together. Negative values relative to other studies were because of excluding pine straw income for longleaf pine.

\section{CONCLUSION}

This study selected six different scenarios across site indices and silvicultural regimes for loblolly, slash, and longleaf pines in the Lower Coastal Plain region of South Georgia. We analyzed the difference due to income from forest products only; income from forest product and pine straw; income from forest product, pine straw, and net stored carbon; and income from forest product, pine straw, net stored carbon, and net water yield. We used a similar set of assumptions for understanding differences in profitability across southern pines. We also performed sensitivity and risk analyses to understand the effects of changing prices on the LEVs of southern pines. The financial risk of growing longleaf pine was lower than that of other southern pines. While LEV was highest for loblolly, adding pine straw income was specifically beneficial for longleaf and slash pines. Also, the income from the net stored carbon increased the LEVs and rotation ages for all selected pines. The income from the net water yield decreased the LEVs in the presence of net carbon payments. The LEVs of longleaf pine were not higher than those of other species even in the presence of payment for pine straw and ecosystem services, suggesting that incentives are needed to promote longleaf pine plantations. The emerging market for longleaf pine straw could help in restoring the species without much governmental support, but more research is needed for ascertaining the effect of a shorter rotation age of longleaf plantations on the conservation value at the landscape level.

We considered income from pine straw in the study; however, markets for pine straw are geographically limited and not available to landowners throughout the longleaf pine range. Additionally, terrain, getting the stands clean for raking, and good road access can affect the production of pine straw. Hence, geographical, topographic, and the available market should be considered while considering income from pine straw. In addition, RCW are adapted to old-growth forests, and the benefits considered in our study do not use wildlife conservation values. We followed a clear-cut regime for longleaf pine in the study. However, uneven management of longleaf pine is gaining popularity among forest landowners in the tri-state region of Georgia, Florida, and Alabama. Future research should focus on the economics of uneven-aged management of longleaf pine stands, as it potentially holds the promise of continuous flow of ecosystem services while providing regular income flows. We did not include an economic value for biodiversity service provided by selected pine species, as these species provide different levels of 
habitat to several species, including endangered species (Van Lear et al., 2005). There are uncertainties associated with evaluations that focus on biodiversity services, as it is difficult to determine direct market prices for species conservation. Future research should incorporate biodiversity values in the economic analysis for ascertaining the economic trade-offs across southern pines, especially in South Georgia.

Our study will guide policymakers and other stakeholder groups in optimizing available financial resources for increasing the area under longleaf pine in the Southern United States. Our research will also inform private forest landowners in Southern United States for understanding the economics of longleaf pine relative to other pines for informed decision making.

\section{DATA AVAILABILITY STATEMENT}

Publicly available datasets were analyzed in this study. This data can be found here: University of Florida, Carbon Resources Science Center.

\section{AUTHOR CONTRIBUTIONS}

KP: conceptualization, methodology, formal analysis, validation, visualization, and writing - original draft. PD: funding

\section{REFERENCES}

Alavalapati, J. R. R., Stainback, G. A., and Carter, D. R. (2002). Restoration of the longleaf pine ecosystem on private lands in the US South: an ecological economic analysis. Ecol. Econ. 40, 411-419. doi: 10.1016/s0921-8009(02) 00012-5

Bauer, D. M., Cyr, N. E., and Swallow, S. K. (2004). Public preferences for compensatory mitigation of salt marsh losses: a contingent choice of alternatives. Conserv. Biol. 18, 401-411. doi: 10.1111/j.1523-1739.2004.00367.x

Burgess, K., Cohen, A., MacCleery, R., Marshall, S., Norris, M., and Sheppard, L. (2017). Harvesting the Value of Water: Stormwater, Green Infrastructure, and Real Estate. Washington, DC: Urban Land Institute.

Conrad, I. V., and Joseph, L. (2018). Costs and challenges of log truck transportation in Georgia, USA. Forests 9:650. doi: 10.3390/f9100650

Dickens, D. E., Moorhead, D. J., Bargeron, C. T., Morris, L. A., Ogden, L. A., and McElvany, B. C. (2012). A summary of pine straw yields and economic benefits in loblolly, longleaf and slash pine stands. Agroforestry Syst. 86, 315-321. doi: 10.1007/s10457-012-9542-4

Dickens, D., Moorhead, D., and Sunday, J. (2014). Economics of Growing Loblolly, Longleaf and Slash Pine to Various Rotation Ages with Three Stumpage Price Sets, Four Establishment Cost Sets, Four Discount Rates, with and without Pine Straw - Soil Expectation Value. Athens, GA: University of Georgia, Warnell School of Forestry and Natural Resources -Center for Invasive Species and Ecosystem Health.

Dickens, E. D., Dangerfield Jr, C. W., and Moorhead, D. J. (2003). "Short-rotation management options for slash and loblolly pine in southeast Georgia, USA," in Proceedings of the 2003 Southern Forest Economics Workshop, 61-65.

Dyer, J. F., Barlow, R. J., Kush, J. S., and Gilbert, J. C. (2012). "Pine straw production: from forest to front yard," in Proceedings of the 16th Biennial Southern Silvicultural Research Conference. e-General Technical Report SRS156, Vol. 156, ed. J. R. Butnor (Asheville, NC: US Department of Agriculture Forest Service, Southern Research Station), 100-108.

Faustmann, M. (1995). Calculation of the value which forest land and immature stands possess for forestry. J For Econ, 1, 7-44.

Gibson, M. D., McMillin, C. W., and Shoulders, E. (2007). Moisture content and specific gravity of the four major southern pines under the same age and site conditions. Wood Fiber Sci. 18, 428-435. acquisition, conceptualization, methodology, and writing review and editing. Both authors contributed to the article and approved the submitted version.

\section{FUNDING}

This work is supported by the United States Department of Agriculture National Institute Food and Agriculture through an award \# 2017-67023-26274.

\section{ACKNOWLEDGMENTS}

The authors are thankful to Drs. Dickens and Kianne (University of Georgia), Susaeta and Sharma (University of Florida) for their insights on growth and yield modeling in the US South.

\section{SUPPLEMENTARY MATERIAL}

The Supplementary Material for this article can be found online at: https://www.frontiersin.org/articles/10.3389/ffgc.2021. 610106/full\#supplementary-material

Glenn, J. V. (2012). Economic Assessment of Landowner Incentives: Analyses in North Carolina and Malawi." Ph.D. thesis. Raleigh, NC: North Carolina State University.

Gonzalez-Benecke, C. A., Jokela, E. J., and Martin, T. A. (2012). Modeling the effects of stand development, site quality, and silviculture on leaf area index, litterfall, and forest floor accumulations in loblolly and slash pine plantations. Forest Sci. 58, 457-471. doi: 10.5849/forsci.11-072

Gonzalez-Benecke, C. A., Samuelson, L. J., Martin, T. A., Cropper, W. P. Jr., Johnsen, K. H., Stokes, T. A., et al. (2015). Modeling the effects of forest management on in-situ and ex-situ longleaf pine forest carbon stocks. Forest Ecol. Manag. 355, 24-36. doi: 10.1016/j.foreco.2015.02.029

Guldin, J., Rosson, J. F., and Dana Nelson, C. (2016). "Restoration of longleaf pine: the status of our knowledge," in Proceedings of the 18th biennial southern silvicultural research conference. e-Gen. Tech. Rep. SRS-212, Vol. 212, (Asheville, NC: US Department of Agriculture, Forest Service, Southern Research Station), 614.

Hamrick, K., and Gallant, M. (2017). Unlocking Potential: State of the Voluntary Carbon Markets, Ecosystem Marketplace. Washington, DC.: Forest Trends' Ecosystem Marketplace.

Harrington, T. B. (2001). Silvicultural Approaches for Thinning Southern Pines: Method, Intensity, and Timing. Macon, GA: Georgia Forestry Commission.

Hartman, R. (1976). The harvesting decision whena standing forest has valuea. Econ. Inq. 14, 52-58. doi: 10.1111/j.1465-7295.1976.tb00377.x

Johnsen, K. H., Butnor, J. R., Kush, J. S., Schmidtling, R. C., and Dana Nelson, C. (2009). Hurricane Katrina winds damaged longleaf pine less than loblolly pine. South. J. Appl. Forest. 33, 178-181. doi: 10.1093/sjaf/33.4.178

Johnson, R. (2011). The Economics of Longleaf Pine Management: A Road to Making Dollars and Sense. Andalusia, AL: Longleaf Alliance.

Lave, R. (2018). Stream mitigation banking. Wiley Interdiscip. Rev. 5, e1279. doi: $10.1002 /$ wat 2.1279

Maggard, A., and Barlow, B. (2018). Costs \& Trends of Southern Forestry Practices, 2016”. Publication FOR-2051. Auburn, AL: Alabama Cooperative Extension System, Auburn University.

McIntyre, R. K., Guldin, J. M., Ettel, T., Ware, C., and Jones, K. (2018). "Restoration of Longleaf Pine in the Southern United States: A Status Report," in Proceedings of the 19th Biennial Southern Silvicultural Research Conference; 2017 March 14-16; Blacksburg, VA. e-General Technuical Report, SRS-234, Vol. 
2018, ed. J. E. Kirschman (Asheville, NC: US Department of Agriculture), 297-302.

McLaughlin, D. L., Kaplan, D. A., and Cohen, M. J. (2013). Managing forests for increased regional water yield in the southeastern us coastal plain. JAWRA J. Am. Water Resour. Assoc. 49, 953-965. doi: 10.1111/jawr.12073

Miles, P. D. (2019). Forest Inventory EVALIDator web-application Version 1.6. 0.03. St. Paul, MN: US Department of Agriculture.

Mills, S. D., and Stiff, C. T. (2013). "Financial Performance of Loblolly and Longleaf Pine Plantations," in Proceedings of the 15th Biennial Southern Silvicultural Research Conference. e-General Technical Report SRS-GTR-175, Vol. 175, ed. J. M. Guldin (Asheville, NC: US Department of Agriculture), 183-191.

Mingie, J. C., and Mengak, M. T. (2014). UGA Survey Shows Average Deerlease Prices. Available online at: http://www.gon.com/news/uga-survey-showsaverage-deer-lease-prices (accessed March 27, 2020).

Nakajima, T., Shiraishi, N., Kanomata, H., and Matsumoto, M. (2017). A method to maximise forest profitability through optimal rotation period selection under various economic, site and silvicultural conditions. N. Z. J. Forest. Science 47, $1-13$.

NRCS (2019). Longleaf Pine Range. Beltsville, MD: USDA.

Oswalt, C. M., Cooper, J. A., Brockway, D. G., Brooks, H. W., Walker, J. L., Connor, K. F., et al. (2012). History and Current Condition of Longleaf Pine in the Southern United States. General Technical Report-Southern Research Station, USDA Forest Service SRS-166. Ashville, NC: Southern Research Station.

Prestemon, J. P., and Abt, R. C. (2002). "Timber products supply and demand," in The Southern Forest Resource Assessment. General Technical Report GTRSRS-53, eds D. N. Wear and J. G. Greis (Asheville, NC: USDA-Forest Service, Southern Research Station), 299-325.

Ruseva, T., Marland, E., Szymanski, C., Hoyle, J., Marland, G., and Kowalczyk, T. (2017). Additionality and permanence standards in California's Forest Offset Protocol: a review of project and program level implications. J. Environ. Manag. 198, 277-288. doi: 10.1016/j.jenvman.2017.04.082

Samuelson, L. J., Stokes, T. A., and Johnsen, K. H. (2012). Ecophysiological comparison of 50-year-old Longleaf Pine, Slash Pine and Loblolly Pine. Forest Ecol. Manag. 274, 108-115. doi: 10.1016/j.foreco.2012.02.017

Samuelson, L. J., Stokes, T. A., Butnor, J. R., Johnsen, K. H., GonzalezBenecke, C. A., Anderson, P., et al. (2014). ecosystem carbon stocks in Pinus palustris forests. Can. J. Forest Res. 44, 476-486. doi: 10.1139/cjfr-2013-0446

Simoes, D., Mosquera, G. A. D., Batistela, G. C., Passos, J. R. S., and Fenner, P. T. (2016). Quantitative analysis of uncertainty in financial risk assessment of road transportation of wood in uruguay. Forests 7:130. doi: 10.3390/f7070130

Siry, J. P. (2002). "Intensive timber management practices," in The Southern Forest Resource Assessment. General Technical Report GTR-SRS53, eds D. N. Wear and J. G. Greis (Asheville, NC: USDA-Forest Service, Southern Research Station), 327-340.

Stanturf, J. A., Goodrick, S. L., and Outcalt, K. W. (2007). Disturbance and coastal forests: a strategic approach to forest management in hurricane impact zones. Forest Ecol. Manag. 250, 119-135. doi: 10.1016/j.foreco.2007.03.015
Stubbs, M. (2014). Conservation Reserve Program (CRP): Status and Issues. Washington, DC: Congressional Research Service.

Sun, G., Caldwell, P. V., and McNulty, S. G. (2015). Modelling the potential role of forest thinning in maintaining water supplies under a changing climate across the conterminous United States. Hydrol. Process. 29, 5016-5030. doi: 10.1002/hyp.10469

Susaeta, A., and Gong, P. (2019). Economic viability of longleaf pine management in the Southeastern United States. Forest Policy Econ. 100, 14-23. doi: 10.1016/ j.forpol.2018.11.004

Susaeta, A., Soto, J. R., Adams, D., and Allen, D. (2016). Economic sustainability of payments for water yield in Slash Pine Plantations in Florida. Water 8:382. doi: $10.3390 /$ w8090382

Taylor, E., and Foster, C. D. (2004). Producing Pine Straw in East Texas forests". Publication B-6145. College Station, TX: Texas cooperative extension.

TMS (2020). Timber Mart-South: Southwide Average Prices. Athens, GA. Available online at: http://www.timbermart-south.com (accessed April 4, 2020).

Van Lear, D. H., Carroll, W. D., Kapeluck, P. R., and Johnson, R. (2005). History and restoration of the longleaf pine-grassland ecosystem: implications for species at risk. Forest Ecol. Manag. 211, 150-165. doi: 10.1016/j.foreco.2005. 02.014

Walton, B. (2010). The Price of Water: A Comparison of Water Rates, Usage in 30 US Cities. Traverse City, MI: Circle of Blue, 26.

Wear, D. N., and Greis, J. G. (2012). The Southern Forest Futures Project: Summary Report". General Technical Report SRS-GTR-168. Asheville, NC: USDA-Forest Service, 54.

World-Bank and ECOFYS (2017). Carbon Pricing Watch, 2017. Washington DC: World Bank.

Wuebbles, D. J., Fahey, D. W., and Hibbard, K. A. (2017). Climate Science Special Report: Fourth National Climate Assessment, Vol. I. Washington, DC: US Global Change Research Program.

Zhao, D., Kane, M., Borders, B., Subedi, S., and Akers, M. (2012). Effects of cultural intensity and planting density on stand-level aboveground biomass production and allocation for 12-year-old loblolly pine plantations in the Upper Coastal Plain and Piedmont of the southeastern United States. Canadian Journal of Forest Research, 42, 111-122. doi: 10.1139/x11-166

Conflict of Interest: The authors declare that the research was conducted in the absence of any commercial or financial relationships that could be construed as a potential conflict of interest.

Copyright (C) 2021 Paudel and Dwivedi. This is an open-access article distributed under the terms of the Creative Commons Attribution License (CC BY). The use, distribution or reproduction in other forums is permitted, provided the original author(s) and the copyright owner(s) are credited and that the original publication in this journal is cited, in accordance with accepted academic practice. No use, distribution or reproduction is permitted which does not comply with these terms. 